\title{
The diversity of Smilax (Smilacaceae) in Besiq-Bermai and Bontang Forests, East Kalimantan, Indonesia
}

\author{
SITI SOFIAH ${ }^{1, \vartheta}$, LULUT DWI SULISTYANINGSIH ${ }^{2, v \varphi}$ \\ ${ }^{1}$ Purwodadi Botanic Gardens, Indonesian Institute of Sciences. Jl. Raya Surabaya-Malang Km. 65, Purwodadi, Pasuruan 67163, East Java, Indonesia. \\ Tel./fax.: +62-343-615033, `email: sofie2291@yahoo.com \\ ${ }^{2}$ Herbarium Bogoriense, Botany Division, Research Centre for Biologi, Indonesian Institute of Sciences. Jl. Raya Jakarta-Bogor Km. 46, Cibinong, Bogor \\ 16911, West Java, Indonesia. Tel./fax.: +62-21- 8765067, +62-21-8765059, `^email: lulutjv@ gmail.com
}

Manuscript received: 26 October 2018. Revision accepted: 31 December 2018.

\begin{abstract}
Sofiah S, Sulistyaningsih LD. 2019. The diversity of Smilax (Smilacaceae) in Besiq-Bermai and Bontang Forests, East Kalimantan, Indonesia. Biodiversitas 20: 379-387. The genus Smilax has taxonomic complexity problems and spacious distribution. Taxonomic study to reveal the diversity of Smilax species had been done in some regions, such as America, China, Japan, Thailand, and Indonesia. However, there is lack of information of Smilax species diversity in Kalimantan especially in East Kalimantan which lies in Sundaland biogeographic. This study was carried out to explore and record the diversity of Smilax species including the ecological and environmental data in Besiq-Bermai and Bontang forests in East Kalimantan, Indonesia. This research conducted on February and August in 2012 and July-August 2015 using exploration methods. Purposive random sampling was used to do the botanical sampling. The principal component analysis (PCA) was performed to determine the relationships between environmental components and Smilax species occurrences. There were five species of Smilax which were housed in those forests in East Kalimantan, namely, Smilax leucophylla Blume, Smilax gigantea Merr., Smilax odoratissima Blume, Smilax zeylanica L., and Smilax modesta A.DC. Smilax leucophylla and Smilax zeylanica are the most widely used by the local people for medicine. The taxonomic description, distribution, use, and vernacular name were given. The environmental factors that contribute significantly to Smilax's growing environment are temperature and light intensity.
\end{abstract}

Keywords: Diversity, East Kalimantan, physical environment, Smilax, soils

\section{INTRODUCTION}

The genus Smilax firstly described by Linnaeus (1753) and belong for a long time to the family Liliaceae (Engler 1964). Today, they were excluded from the family Liliaceae based on the differences that lie in habit, tendril, anther, and pistil, and then included in the family Smilacaceae and followed by many botanists (Hutchinson 1973; Cronquist 1981, 1988; Takhtajan 1987, 1997; APG II 2003; APG III 2009; APG IV 2016). Smilacaceae is a small monocots family in the order Liliales with its complexities and its controversial taxonomic status since their species determination is extremely difficult. Smilacaceae is dioecious plants, flower infrequently made many herbarium specimens lack flower, show considerable phenotypic variation within populations and even among leaves of the same individual plant. Traditionally, Smilacaceae consist of two genera, Smilax and Heterosmilax which were differing by its connate tepals and the variable number of stamens $(3,6,9-12)$ with connate filaments. However, molecular phylogenetic examination showed that the genus Heterosmilax is nested within the genus Smilax making Smilacaceae as a monogeneric taxon (Cameron and Fu 2006). The genus Smilax comprising $c a .350$ species with widespread distribution, mostly in tropical and subtropical regions. It was characterized by woody climber or vine up to $20 \mathrm{~m}$ long; rhizome tuberous or elongated, often thickened; stem terete, quadrangular or angular, usually with prickles; leave with paired tendrils raise from petiole at apex of sheath, these sometimes reduce and non-functional; petioles with a variably placed pulvinus (articulation) at junction of blade and petiole or above tendrils, or this absent; blade simple, oblong-ovate to ovate or linear-lanceolate, shiny to waxy, membranaceous to very coriaceous, deciduous to persistent, margin entire, symmetric or asymmetric, main veins prominent, 3-7 venation distinctly reticulate; inflorescence axillary or terminal panicles, simple or compound racemes, spikes or umbels; flower erect, actinomorphic, unisexual, trimerous, hypogynous; fruit black, purple or red berry; seed single to several, globose to ovoid-angular, pale yellow to dark brown (Cameron and Fu 2006). Koyama (1960) divided Smilax into eight sections based on differences in morphological characters such as flower, inflorescence and habit, i.e. (1) section China Koyama, (2) section Coilanthus A.DC, (3) section Nemexia Raf., (4) section Macranthae Kunth, (5) section Nervomarginatae Koyama, (6) section Pleiosmilax (Seem) A.DC, (7) section Smilax L. Koyama, (8) section Vaginatae Koyama.

Sarsaparilla is the popular name of Smilax species. They have been used in folk medicine as tonic against rheumatism and anti-syphilitic since the sixteenth century. They also play a role in the remedy of gonorrhea, syphilis, rheumatism, abscesses and also in the manufacture of steroidal hormones, even as candied fruit (Tobias 2007). 
Smilax produces rhizomes that are used in folk medicine and beer brewing, while the stems are used in crafts. The roots were exported widely from the Neotropics for use in the treatment of syphilis. It was not clear which species of Smilax contain the active components since the phenotypic plasticity of the species in the Neotropics (FerrufinoAcosta 2010). The ability of Smilax species that can provide shelter and food for wildlife and also provide humans with medicine, food, and dye making Smilax spp. as an important species.

Phytochemistry study to reveal bioactive components of Smilax species have been conducted almost in China (Xu et al. 2005) and America (Rugna et al. 1999), while the systematic study had been undertaken to investigate the phylogenetic relationship among East Asian species and American species which belonged to section Nemexia $(\mathrm{Fu}$ et al. 2005). Taxonomic study to reveal diversity and to solve complexity of Smilacaceae have been conducted in America and the Caribbean Islands (Ferrufino-Acosta 2010; Denk et al. 2015), Brazil (Martins et al. 2013), China (Chen and Koyama 2000; Qi et al. 2013a, b), Thailand (Moore et al. 2010), Java (Backer and Bakhuizen v.d. Brink 1968; Ungson and Sastrapradja 1976), Borneo (Merrill 1921). Merrill (1921) reported there were five Smilax found in Borneo ( $S$. borneensis A.DC, S. helferi A.DC, S. korthalsii A.DC, $S$. laevis Wall.Cat., $S$. leucophylla Blume) and two species of Heterosmilax $(H$. borneensis A.DC and H. indica A.DC).

Borneo is the third largest island of the world. It is most diverse part of the Sundaland hotspot, one of the world's 25 biodiversity hotspots (Myers et al. 2000). Borneo lost $30.2 \%$ of its forest cover, where only $17.4 \%$ of forest remain intact and $36.4 \%$ of the land is degraded (Gaveau et al. 2014). The Province of East Kalimantan, Indonesia lies in the Sundaland biogeographic province which possesses extraordinary biodiversity, with some 15,000 endemic plants (Myers et al. 2000). Elevation in East Kalimantan ranges from sea level to over $2,500 \mathrm{~m}$ in the interior and tends to vary inversely with total species richness, although endemism in some taxa (e.g. birds) increases with elevation (Sujatnika et al. 1995). The forests are dominated by trees in the family Dipterocarpaceae and Borneo is the center of diversity for this particular group (Ashton 2004). The dominance of genus Shorea in the regions closely associated with the island of Borneo as a center of diversity of the genus. Soil chemical content that most influence on the species of the genus Shorea is soil organic matter which is quite varied with range $1.12 \%-3.18 \%$ (low to moderate). In this forest, plant species are commonly found, namely Dillenia excelsa, Syzygium spp. and Shorea parvifolia. Saplings habitus $(\mathrm{D}<30 \mathrm{~cm})$ dominated by Macaranga triloba. Herbs in this forest area are dominated by Phrynium jagorianum. Several endemic orchid of Borneo were riching the forest, namely Grammatophyllum speciosum, Phalaenopsis modesta, and Coelogyne foerstermannii (Sofiah 2018).

The research site was coal mining targeted area for reforestation and restoration after mining. The lowland area of East Kalimantan was almost completely covered by tropical rainforest before the 1970s (Eichhorn 2006). However, there are a lack of up to date information on Smilax diversity and ecological factors in Borneo. The diversity and distribution of many plant species are influenced by ecological factors including edaphic factors (Vleminckx 2015). The soil typical of Kalimantan are much dominated by red yellow podzolic soils, such as in Besiq Bermai (Sofiah 2018) and Bontang Forest. From observations in the field, there is a high value of alkaline saturation and Fe content. Based on previous research, especially besiq bermai village, forest areas are dominated by Dipterocarpaceae (Sofiah 2018). Smilax research conducted at the coal-mining site is one of a series of studies in the effort to conserve plants on pre-mining area.

The aims of this study was to explore and record the diversity of Smilax species including the ecological and environmental data in Besiq-Bermai Village and Bontang forests of East Kalimantan, Indonesia. Borneo Smilax research and its ecological character are the basic for understanding conservation efforts, especially ex situ conservation in botanic gardens.

\section{MATERIALS AND METHODS}

\section{Study area}

The field study was done in two secondary forests in East Kalimantan, Indonesia, i.e. (i) Besiq Village and Bermai Village, Damai Sub-District, East Kutai District in N 9905934.554001633 E 326615.6294839026; (ii) Protected forest in Bontang, East Kutai in N 0009.52.4 E 117.21.55.1. Both of locations are lowland rainforest. In research sites, the daily climate's average ranged between $21.6^{\circ} \mathrm{C}-31.8^{\circ} \mathrm{C}$ for temperature, $34-58 \%$ for humidity and 41-1526 Lux for light intensity. Forest area in BesiqBermai and Bontang Protected Forest have altitude in 114$139 \mathrm{~m}$ asl., belongs to the category of flat.

\section{Data collections}

Field research to collect new specimens were carried out by using exploration method. The sampling method used was purposive random sampling (Rugayah et al. 2004), in which sampling localities were randomly selected by considering factors that influence the existence of Smilacaceae species. Data or information recorded from the field include location; altitude, longitude, and latitude; vernacular name; plant general habit and characters which are not visible when it has become herbarium specimens. Specimen were preserved in the form of mounted herbarium specimens as per standard field and herbarium techniques (Djarwaningsih et al. 2002). Distribution survey was conducted to provide information on diversity and distribution of Smilax species. Whereas environmental factors survey which consists of temperature, humidity, light intensity, soil physical and chemical properties were conducted to provide the relationship between Smilax species and their environment. Those environmental factors 


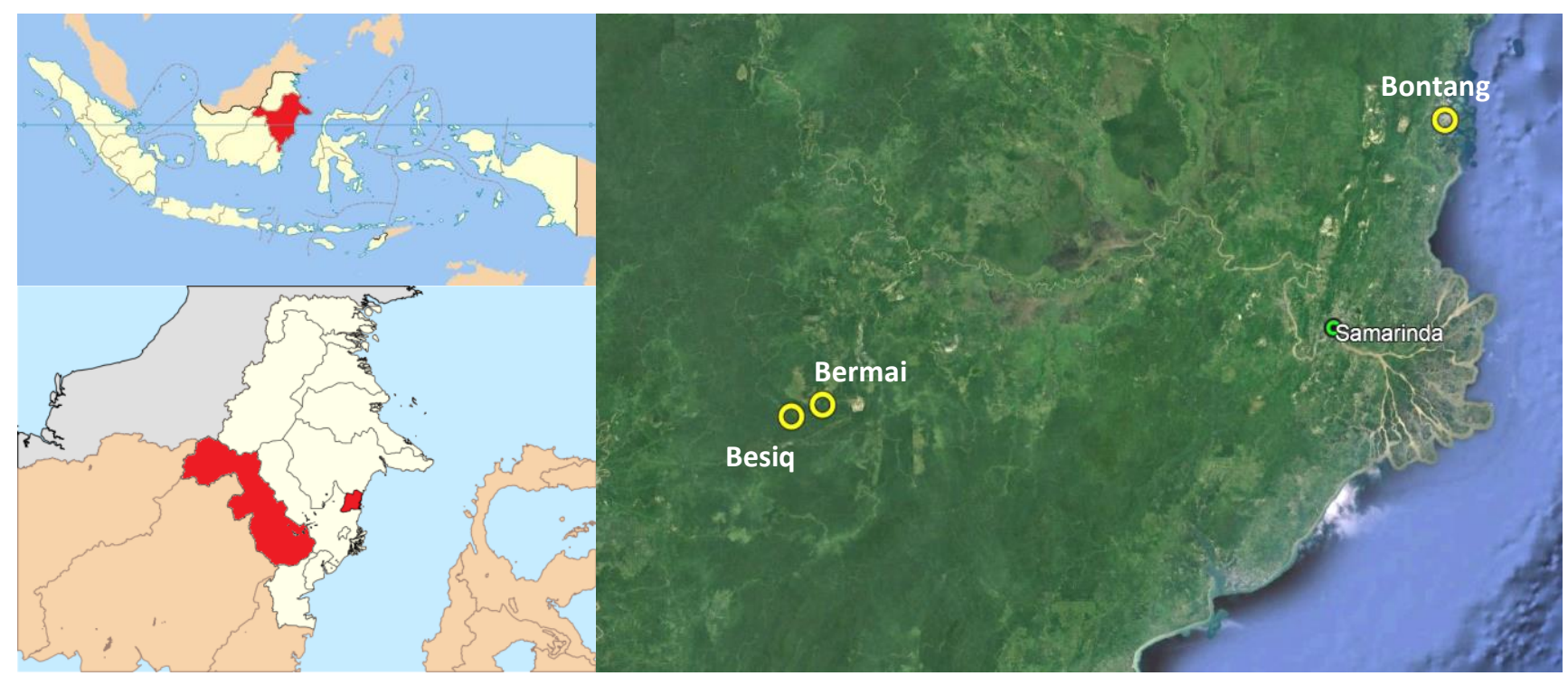

Figure 1. Location of Besiq-Bermai (West Kutai District) and Bontang forests in East Kalimantan, Indonesia. Besiq-Bermai in N 9905934.554001633, E 326615.6294839026, and Bontang forest in N 0009.52.4, E 117.21.55

recorded with purposive random sampling, in which the data recorded is determined based on the presence of Smilax species. Field research was conducted on February and August 2012, and July-August 2015 in Besiq-Bermai and Bontang forest area, East Kalimantan. Identification of Smilax is done in Purwodadi Botanic Garden, Pasuruan, Indonesia and Herbarium Bogoriense (BO), Research Center for Biology, Indonesian Institute of Sciences (LIPI), Bogor, Indonesia.

\section{Data analysis}

Principal Component Analysis (PCA) used to analyze the relationship between Smilax and their natural habitat. Principal Component Analysis is used to simultaneously see the overall relationship between the variables observed for interpretation and relationship analysis.

\section{RESULTS AND DISCUSSION}

A total five Smilax species, namely Smilax leucophylla Blume, Smilax gigantea Merr., Smilax odoratissima Blume, Smilax zeylanica L., and Smilax modesta A.DC. were found in the Besiq-Bermai and Bontang Forests, East Kalimantan. In Besiq-Bermai forest, there are found four species of Smilax, namely Smilax gigantea, Smilax odoratissima, Smilax leucophylla, and Smilax zeylanica. Smilax in Bontang forest found four species, namely Smilax modesta, Smilax zeylanica, Smilax gigantea, and Smilax leucophylla. In this forest, Smilax is widely grown on the banks of the former forest land aperture. In general, they were found in the forest moistly and covered shady trees.

\section{Identification key}

Identification key of Smilax in the Besiq-Bermai and Bontang forests

1. a. Leaves coriaceous and not glaucous below .......... 2

b. Leaves chartaceous and glaucous below...S. leucophylla

2. a. Branches not rough, but often spiked ................. 3

b. Branches are very rough due to numerous warts .. S. odoratissima

3. a. Leaves base narrowed, costas usually 3 or $5 \ldots \ldots \ldots .4$

b. Leaves base broadly rounded and deeply cordate,

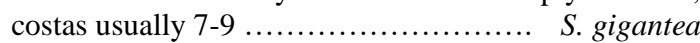

4. a. Inflorescences are borne on distal part of branches, bearing 1 to 5 umbels ...................... S. modesta

b. Inflorescences are borne terminal or axillary, bearing 1-or 2-3 umbels ....................... S. zeylanica

\section{Taxonomic description}

Smilax gigantea Merr. (Figure 2.A-D)

Smilax gigantea. J. Straits Branch Roy. Asiat. Soc. (1922) 85: 161 (—Type: Ramos M sn., 1850 (K))

Description: A large, coarse, woody vine, the inflorescence-bearing branches terete, brown, striate, 8 to $10 \mathrm{~mm}$ in diameter, armed with scattered, very stout, narrowly pyramidal spines about $2 \mathrm{~mm}$ in length. Leaves broadly ovate, chartaceous to subcoriaceous, about $35 \mathrm{~cm}$ long and wide,apex very shortly and abruptly acuminate, base broadly rounded and deeply cordate, upper surface smooth, glabrous, shining, brownisholivaceous, lower surface brownish, rather softly and densely pubescent, the indumentum short, not at all stellate; petioles stout, about $7 \mathrm{~cm}$, long, the sheating basal portion; domatia broadly clasping nodes, ovate to acute, brown to black in colour; nerves about 9 , all basal, prominent, the reticulations rather lax. Infructescences about $30 \mathrm{~cm}$ long, 
the umbels racemosely disposed, from 3 to 6 in the axil of each brat, their peduncles 7 to $10 \mathrm{~cm}$ long, the rachis usually about $20 \mathrm{~cm}$ in length, 4 to $6 \mathrm{~mm}$ wide, strongly flattened, the umbels up to 25 in each infructescence. Fruits globose, shining when dry, about $1 \mathrm{~cm}$ in diameter, 12 to $25 \mathrm{~cm}$ in each umbel, their pedicels slender, 1.5 to 1.8 $\mathrm{cm}$ in length (Merrill 1921).

Distribution. It is native to Borneo (WCSP 2018).

Habitat. Dipterocarp forest. Smilax gigantea is commonly found in the open area, such as edge forest.

Uses. The root is used as medicine for treating hernia By Dayak tribe (Tomery; Dayak tribe, 2018, pers. comm)

Vernacular name. Canar (Indonesian), Bomooy (Dayak tribe-Kalimantan).

Notes. This species develops domatia that are very similar to those of $S$. borneensis both in form and size. Smilax borneensis and S. gigantea have ovate to acute domatia which encloses the stem from all sides. Mature domatia are hard-walled that reach a length of up $5.5 \mathrm{~cm}$ (Heckroth et al. 2004). S. gigantea is more commonly found in the edge of an open forest area, especially in sloping land areas. Higher light intensity causes $S$. gigantea to develop faster, and appears to be like a ground cover crops. From the results of observations in the field, $S$. gigantea develops more quickly in the wet months, especially in September-November. Further ecological studies of $S$. gigantea needs to do to assign the species conservation status in the wild.

\section{Smilax leucophylla Blume (Figure 2.E-G)}

Smilax leucophylla Blume. Enum. Pl. Javae (1827) 18 (-Type: Blume, CL sn. (L))

Description: Woody climber up to $18 \mathrm{~m}$ long; branches stout, armed with patent or recurved prickles $2-3.5 \mathrm{~mm}$ long, internodes subtere, $11-20 \mathrm{~cm}$ long, 3-5 mm thick. Leaves leathery; blades broadly ovate to ovate-oblong, leathery, 10-32 cm long, 4-22 cm wide, fresh green above, glaucous below, apex acuminate, cordate at base, costas 5 (rarely 7), leaf margin regular, pruinose beneath, yellowish or greenish when dry; petiole $4-5 \mathrm{~cm}$ long, breaking off at bottom between sheath and blade, obtusely trigonous, often weakly incurved, sheathing portion 15-20 mm long, with acute wings $2-4 \mathrm{~mm}$ in width; tendrils on branches, attaining $1 / 3$ to $1 / 2$ the length of blade. Inflorescences $2-6$ umbellate, axis stout, 3-4 cm long, rachis arising at young branch, prophyllate at base, almost wholly enclosed in the subtending petiolar sheath; peduncles of umbels verticillate, 2-to 4-nate at 1 to 3 nodes, $8-10 \mathrm{~cm}$ long, divergent, the base with deltoid bracts $c a .7 \mathrm{~mm}$ long. Staminate umbels densely 15-to 25-flowered, ca. $5 \mathrm{~mm}$ across. Staminate perianth $0.8-1 \mathrm{~cm}$ long, venation uninerved; tepals reflexed above, outer ones oblong, $2 \mathrm{~mm}$ wide, obtuse at apex, inner ones linear. Stamens 6, subequal with the perianth; filaments slender, $0.8-1 \mathrm{~mm}$ long; cross section of peduncle compressed; anthers lanceolate, 2 locules, $1.5 \mathrm{~mm}$ longs. Pistillate umbels 10 -to 20-flowered; receptacles globose, 6-8 $\mathrm{mm}$ across; rays wiry, up to $25 \mathrm{~mm}$ long. Pistillate flowers unknown. Fruit berries, globose, $1 \mathrm{~cm}$ across, black at maturity.
Distribution. Smilax leucophylla could be found in Peninsular Malaysia, Java, Borneo and the Philippines to New Guinea and northern Australia (van Valkenburg 2002).

Habitat. In Besiq-Bermai Village and Bontang forest, Smilax leucophylla usually found in open and covered areas. The field study showed that $S$. leucophylla was more common in the former an open area of land openings and thrives there.

Uses. The roots and leaves were used for treating cancer. The rhizomes are considered blood purifier and used in cases of syphilis, rheumatism, and skin diseases. Subro (2012) reported that $S$. leucophylla has high chlorophyll content that contributes to the environmental services ecosystem through the amount of oxygen produced and absorbed the carbon dioxide. The young shoots and leaves are edible. The local people in Cidahu usually make them as "lalapan". Stem usable as a substitute for rattan to make some craft. However, S. leucophylla is one of the ground cover plants that contribute to the reduction of air emissions.

Vernacular name. Ubi danau, marsh yam, akarbanar; canargede, canarbokor, canarminyak, cangkores (Sundanese); sarsaparillangputi, banag, kaguno (Philipphines); wanabekira (Papua New Guinea).

Notes. Further ecological studies of S. leucophylla needs to do to assign the species conservation status in the wild. In general, S. leucophylla is more commonly found in area soil-pH range 4-6,2. In addition, S. leucophylla is found in areas with a slope of $80-108^{\circ}$.

\section{Smilax modesta A.DC. (Figure 2.H-I)}

Smilax modesta A.DC. Monogr. Phan. 1 (1878): 185(Type: Zollinger H. 1599 (P))

Description: Climber up to $10 \mathrm{~m}$ long; Stems terete or more angular, spinous with spreading spines 1-2 mm long or unarmed, rather slender-branched, internodes 2-6 cm long, 1-3 mm thick. Leaves mostly small; blade generally oblong to lanceolate, narrowed upwards, 6-8 cm long, 2-5 $\mathrm{cm}$ wide, usually rather long acuminate, acute at apex, thinly, herbaceous, bright green above, paler beneath, not glaucous, costas 5 or 7 including a marginal pair, the median 3 more pronounced than the remainder, united at base for 3 to $7 \mathrm{~mm}$, highly raised with sharp edge on lower surface, distinct on upper surface, lateral veinlets obliquely spreading, straightish, forming not very elongate, fine reticulations; petioles $5-20 \mathrm{~mm}$ long with narrow basal sheath; wings $0.5-1 \mathrm{~mm}$ wide; tendrils vestigial on flowering leaves, up to $12 \mathrm{~cm}$ on sterile leaves and stems. Inflorescences borne on a distal part of branches, bearing 1 to 5 umbels; main rachis $0.5-4.5 \mathrm{~cm}$ long; prophyll broadly ovate, acuminate, 4-6 mm long, peduncles with convex basal scale, sometimes elongated into a leafy branch. Staminate umbels densely 10--flowered, 2-3 cm across. Pistillate umbels 15-30-flowered, 2-3 cm across. Staminate perianth pale-green, 4.5-5 $\mathrm{mm}$ long; outer tepals oblong or oblong-oblanceolate, rounded at apex, 4-7 mm long, 1-1.2 $\mathrm{mm}$ wide, inner ones linear-oblong, obtuse, 0.3-0.5 mm wide, both recurved at anthesis. Anthers oblong, $1 \mathrm{~mm}$ long; filaments 3-3.5 mm long. Pistillate perianth $3 \mathrm{~mm}$ long; outer tepals elliptic, subobtuse, $1.5 \mathrm{~mm}$ wide, inner 
ones elliptic-oblong, $0.75 \mathrm{~mm}$ wide, tapering to subobtuse tip, both patent to weakly recurved; ovary ellipsoid, $\mathrm{ca} 2$ $\mathrm{mm}$ long, $1 \mathrm{~mm}$ thick; stigmas downward, nearly $1 \mathrm{~mm}$ long; staminodes 3, needle-like, $1.5 \mathrm{~mm}$ long. Fruit berries 1-6, 5-6 mm across, becoming dirty gray at maturity, 1-or 2-seeded.

Distribution. It is native to Borneo, Java, and Sumatra (WCSP 2018).

Habitat. In Dipterocarp forest. Smilax modesta is commonly found in shaded area.

Vernacular names.Areuj canar, canar, canar beurit, canar kembang (Sundanese).

Notes. This species has been much confused with $S$. zeylanica, which can be distinguished by its leave shape. $S$. modesta mostly oblong and smaller than $S$. zeylanica. $S$. modesta is only found in Bontang forest in small population. Further ecological studies of $S$. modesta needs to do to assign the species conservation status in the wild, especially because it is rarely found in the forest. There is no information yet about its use by local communities.

\section{Smilax odoratissima Blume (Figure 2.J-K)}

Smilax odoratissima Blume. Enum Pl. Javae (1827) 19

Description: Climber up to $20 \mathrm{~m}$ height. Stems with spines, rough or scabrid; young stems usually purplecolored. Leaves alternate with narrow basal sheaths and paired tendrils; blade oblong-lanceolate, margin entire, 6$13 \times 4-8 \mathrm{~cm}$, base obtuse-acute, apex sub-acuminate; midrib with 2 lateral veins. Petiole 1-2 cm long. Inflorescences terminal or axillary, 1- or 2-3 umbels; peduncle up to $5 \mathrm{~cm}$ long. Flowers dioecious, erect, actinomorphic, hypogynous; pedicels 4-5 mm long; receptacle sub-globose (in the same branch) or lanceolate (between bracteolate). Flower bud oblong or obovateoblong, $5 \mathrm{~mm}$ long. Tepal linear-oblong, opened-revoluted. Stamens 6, in 1-3 whorls; filaments free. Anthers basifixed, latrorse, dehiscing longitudinally, tetrasporangiate. Gynoecium of 3 united carpels, rarely unicarpellate. Ovary 3-locular with basal or axile placentae. Ovulesatropous, borne paired in each loculus. Fruits a red to purplish blackberry, 5-6 $\mathrm{mm}$ in diam. Seeds single to several, globose to ovoid-angular, pale yellow to dark brown. Fl. April-October. $2 n=32$.

Distribution. It is native to Bangladesh, Borneo, Java, Lesser Sunda Islands, Myanmar, Thailand (WCSP 2018).

Habitat. Lowland to montane forests, mostly collected from higher altitudes.

Uses. In ethnomedicinal uses, the root of $S$. odoratissima is used as used as a hemostatic. Root sap is taken to treat dehydration (Faruque 2018).

Vernacular names. Canar bokor, canar kembang, canar wangi (Sundanese).

Notes. S. odoratissima is a synonym from of infraspecific taxa of $S$. bracteata subsp. verruculosa, with densely verruculose and usually sparingly prickly stem and branches.

\section{Smilax zeylanica $\mathrm{L}$.}

Smilax zeylanica L. Species Plantarum (1753) 1029 (Hermann sn (BM)); Smilax ceylanica Oken. Allg.
Naturgesch (1841) 3 (1): 616; Smilax collina Kunth. Enum. Pl. (1850) 5: 261; Smilax elliptica Desv. Ex Ham. Prodr. Pl, Ind. Occid (1825) 58; Smilax elliptica R.Br. Prodr. Fl. Nov. Holl, (1810) 293; Smilax hohenackeri Kunth. Enum. Pl. (1850) 5: 240; Smilax indica Burm.f. Fl. Ind. (1768) 213; Smilax ovalifolia var. nervulosa. Monogr. Phan (1878) 1: 200; Smilax villandia Buch. - Ham. Ex Royle. Ill. Bot. Himal. Mts. (1839)384; Smilax zeylanica var. penangensisA.DC.Monogr. Phan. (1878) 1: 191; Smilax zollingeri Kunth. Enum. Pl. 5 (1850) 5: 241

Description. Climber up to $12 \mathrm{~m}$ long; Stems more or less4-angular, armed, sparingly prickly, prickle 1-2 mm, internodes 3-6 cm long, 1-3 mm thick. Leaves moderate; blade generally elliptic to ovate, base narrowed, 6-10 ×3-7 $\mathrm{cm}$, rounded-truncate at base, contracted above to subacute apex, herbaceous to thinly coriaceous, costas 3 or 5 , often stained with dark red, the median 3 united for 4 to $7 \mathrm{~mm}$ above the base; petioles 9-17 $\mathrm{mm}$ long, sheathing for $c a .4$ $\mathrm{mm}$ from base; wings $0.5-1 \mathrm{~mm}$ wide; tendrils vestigial on flowering leaves, up to $12 \mathrm{~cm}$ on sterile leaves and stems. Inflorescences borne on a distal part of branches, bearing (1-)2-3 umbels; main rachis 0.5-3 cm long; prophyll broadly ovate, acuminate, $4-5 \mathrm{~mm}$ long, peduncles with convex basal scale, sometimes elongated into a leafy branch. Staminate umbels densely 20-40-flowered, 2-3 cm across. Pistillate umbels 20-40-flowered, 2-3 cm across. Staminate perianth pale-green, 3-4 mm long; outer tepals oblong or oblong-oblanceolate, rounded at apex, 4-7 ×1-1.2 $\mathrm{mm}$ wide, inner ones linear-oblong, obtuse, 0.3-0.5 mm wide, both recurved at anthesis. Anthers oblong, $1 \mathrm{~mm}$ long; filaments 3-3.5 mm long. Pistillate perianth $3 \mathrm{~mm}$ long; outer tepals elliptic, subobtuse, $1.5 \mathrm{~mm}$ wide, inner ones elliptic-oblong, $0.75 \mathrm{~mm}$ wide, tapering to subobtuse tip, both patent to weakly recurved; ovary ellipsoid, $c a .2$ $\mathrm{mm}$ long, $1 \mathrm{~mm}$ thick; stigmas downward, nearly $1 \mathrm{~mm}$ long; staminodes 3, needle-like, $1.5 \mathrm{~mm}$ long. Fruit berries 1-6, 5-10 mm across, bright red to blue-black at maturity, 1-or 2-seeded.

Plants flower in May and June with white/green clustered flowers. If pollination occurs, the plant will produce a bright red to blue-black spherical berry fruit about $5-10 \mathrm{~mm}$ in diameter that matures in the fall (Jena 2011). S. zeylanica also often founded in temperature zone, tropics and subtropics worldwide (Babu 2017).

Distribution. It is native to Assam, Bangladesh, East Himalaya, India, Java, Myanmar, Nepal, Solomon Islands, Sri Lanka (Hossain et al. 2013) and Borneo (Trimanto and Sofiah 2018).

Habitat. In Dipterocarp forest. S. zeylanica is more commonly found in the open area.

Uses. The root is used as medicine to treat rheumatism and together with rhizomes and leaf are used in epilepsy (Madhavan 2008), fever, veneral, and skin diseases, sores, swelling and abscesses as they have large amounts of tannin, saponin, 31-norcycloartenol, parilin, phenolic acid and potassium nitrate (Sharma 2018). By Dayak tribe, $S$. zeylanica is used to treating rheumatism and dysentery. The part used for medicine is the root. The part used for medicine is the root which it is boiled with some water, then the boiled water is drunk. 


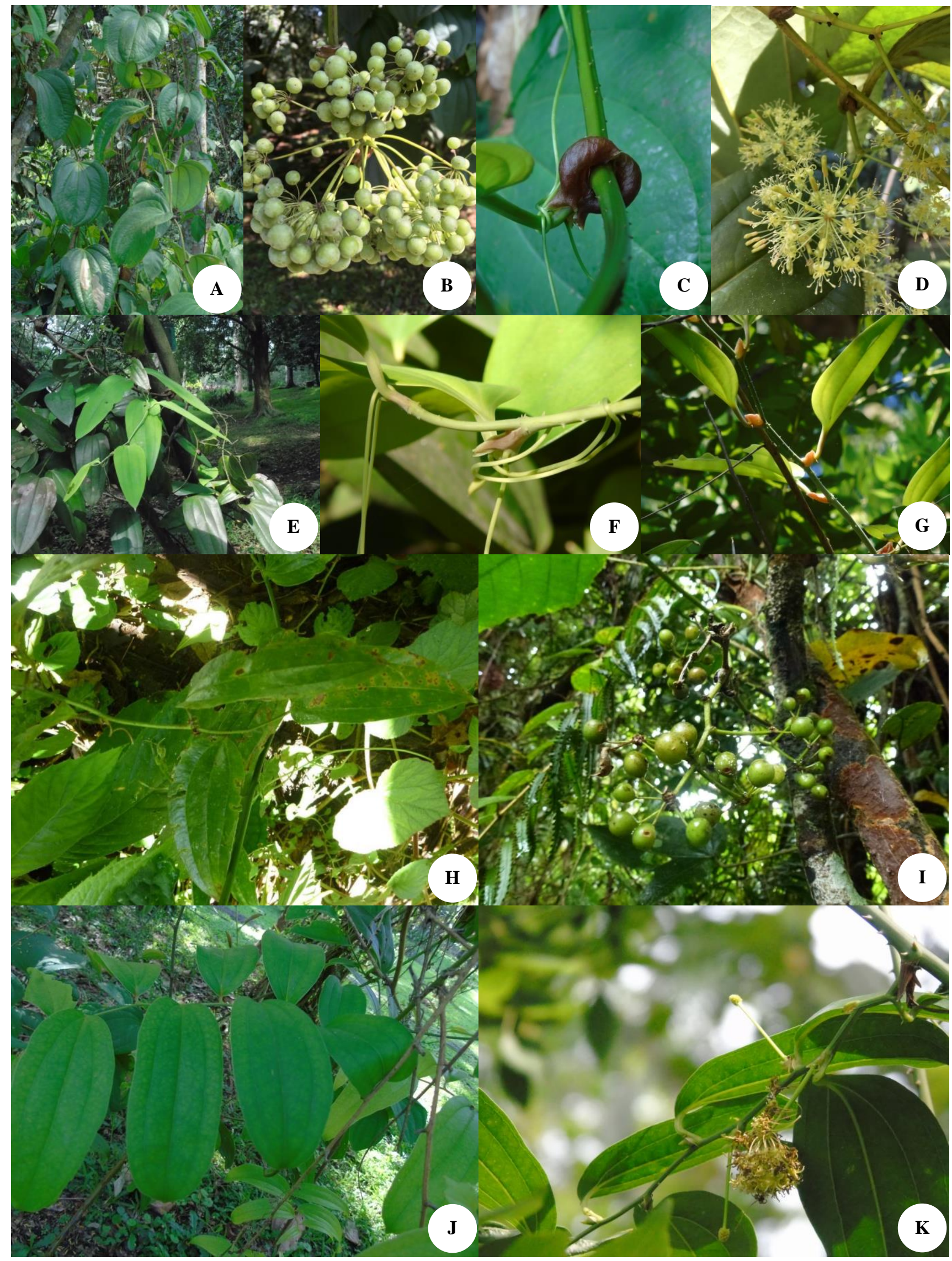

Figure 2. Smilax gigantea. A. Habitus, B. Infructescence, C. Domatia, D. Inflorescence; Smilax leucophylla. E. Habitus, F. Young tendrils, G. Stem articulation; Smilax modesta. H. Habitus, I. Infructescence; Smilax zeylanica. J. Leaves, K. Inflorescence (All photographs by SS, except for H-I by LDS) 
Vernacular names. Canar, canarbeurit, canarbokor, canarlotik, canarlembut (Sundanese), gadung cina, kayu cina utan.

\section{Habitat of Smilax and Its Interaction with abiotic factors}

The most merely interpretable sign of biological is species richness which highlights with different environmental characters (Khan et al.2016). Abiotic variation is a well-known characteristic both in space and time which effect plant communities and population. The soil is an environmental factor that also determines plant growth which is influenced by the organism, climate, topography, time and parent material (Hoveizch 1997). There are many soil factors (variables) that influence the diversity and distribution of plant species, such as organic matter, exchangeable cation, soil types and other soil factors Tanveer et al. (2013) suggest that the Celosia arvensis tends to grow better in neutral and slightly acidic soil as compared to alkaline soil environments.
The topography of Besiq-Bermai and Bontang forests are relatively flat. The soil type in this area is dominated byred-yellow podzolic, that it makes interactions with climate and rainfall typical lowland rain forest, and bean optimal growing environment for the types of Dipterocarp. Soil acidity $(\mathrm{pH})$ of Besiq-Bermai and Bontang forests are ranged from 3.5 to 4.7 , including very acid criteria. Soil organic matter content varies $1.9-5.5 \%$, which belong to the criteria of low to middle. Available phosphorus soil content ranged between 10.6-42.8 ppm, which are included in the high category. Some forests in East Kalimantan have sufficient cover tightly. The lack of sunlight that enters the surface of the ground floor, then causing micro humidity is quite high (80.4-87.3\%). However, daytime temperatures up to reach $32^{\circ} \mathrm{C}$, so the conditions were fairly high humidity and temperatures are high enough during the day, will speed up the process of weathering of existing litter on the forest floor surface. The results of previous research show that edaphic factors that had the highest influence on the occurrence and establishment of flora in Besiq-Bermai forest were total $\mathrm{N}$ and $\mathrm{C} / \mathrm{N}$ ratio (Sofiah 2018).

Table 1. Eigenvalue of Smilax habitat

\begin{tabular}{lll}
\hline PC & Eigenvalue & \% variance \\
\hline 1 & 2.70119 & 54.024 \\
2 & 1.81475 & 36.295 \\
3 & 0.417662 & 8.3532 \\
4 & 0.0663989 & 1.328 \\
\hline
\end{tabular}

\begin{tabular}{lllll}
\hline & PC 1 & PC 2 & PC 3 & PC 4 \\
\hline Elevation & -0.5286 & -0.10424 & 0.73445 & -0.0607 \\
Temperature & 0.53803 & 0.28578 & 0.28948 & -0.72467 \\
Humidity & -0.31315 & 0.59609 & -0.46409 & -0.071633 \\
Light intencity & 0.36153 & 0.55432 & 0.38479 & 0.64326 \\
Soil-pH & 0.44983 & -0.49484 & -0.11552 & 0.22857 \\
\hline
\end{tabular}

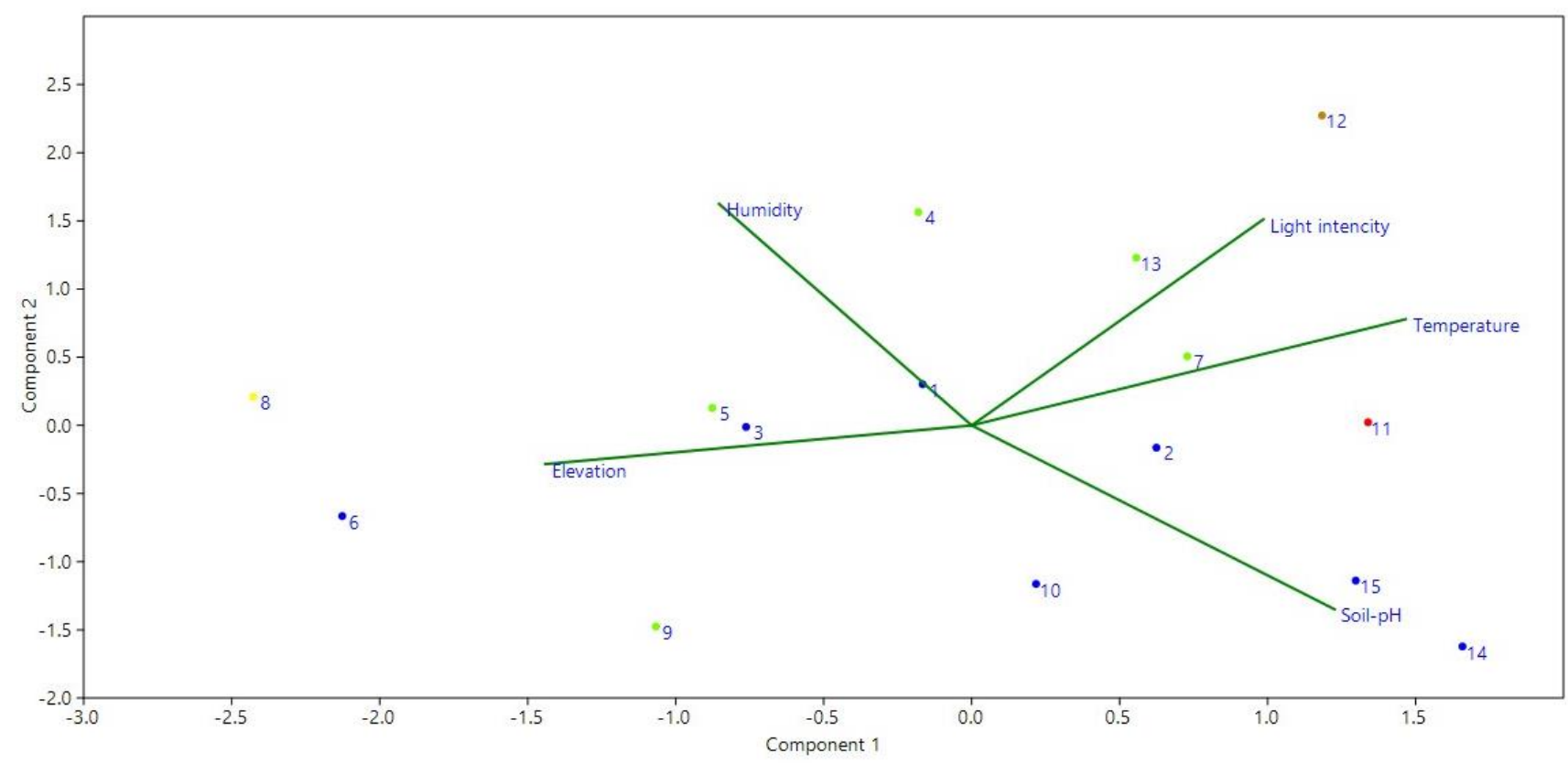

Figure 3. The results of the main components of environmental factors in the presence of Smilax in their habitat. The environmental factors recorded are elevation, humidity, light intensity, temperature, and Soil-pH. Smilax leucophylla $(1,2,3,6,10,14,15) ;$ Smilax gigantea $(4,5,7,9,13)$; Smilax odoratissima (8); Smilax modesta (11); Smilax zeylanica (12). 
Table 2. Environmental variable of Smilax

\begin{tabular}{lccccc}
\hline Species & $\begin{array}{c}\text { Elevation } \\
(\mathbf{m} \text { asl.) }\end{array}$ & $\begin{array}{c}\text { Temperature } \\
\left({ }^{\circ} \mathbf{C}\right)\end{array}$ & $\begin{array}{c}\text { Humidity } \\
(\boldsymbol{\%})\end{array}$ & $\begin{array}{c}\text { Light intensity } \\
(\mathbf{L u x})\end{array}$ & Soil-pH \\
\hline Smilax leucophylla & 100.29 & 28.78 & 79.76 & 2835.94 & 5.06 \\
Smilax gigantea & 78 & 28 & 84.81 & 2749.44 & 4.4 \\
Smilax odoratissima & 139 & 27.05 & 85 & 2245 & 3.5 \\
Smilax modesta & 83 & 31.5 & 80 & 3220 & 5.1 \\
Smilax zeylanica & 84 & 32 & 85.1 & 5330 & 4 \\
\hline
\end{tabular}

Analysis of principal component using PCA (Principal Component Analysis) towards environmental factors consists of five variables, namely elevation, temperature, humidity, light intensity, and soil-pH. Two principal components can explain $90.31 \%$ of all environmental component measured. The first component can explain $54.02 \%$, when the second component can explain $36.29 \%$ of all variable environmental measured. The first component provided more information than the second component (Table 1). This results indicate that between the two component factors, PC 1 provides relatively larger information to describe Smilax habitat conditions. The component of temperature variable is a physical environment variable which is quite influential on the first component factor (PC1), followed by elevation and soil$\mathrm{pH}$. The component of the humidity variable and light intensity is a physical environment variable that affects the second component factor (PC2). The model of the habitat of Smilax in each forest of East Kalimantan with its environmental factors can be formulated based on Table 1. $\mathrm{PC} 1=-0.529$ elevation +0.538 temperature -0.313 humidity +0.361 light intensity +0.449 soil-pH ; PC2 $=$ 0.104 elevation +0.286 temperature +0.596 humidity + 0.554 light intensity-0.495 soil-pH.

Smilax's existence does not correlate closely with one physical factor where it grows, but is spread over various places of growth. However, there are several locations where Smilax is located which correlates very closely with the temperature and light intensity factors (Figure 3). It can be seen from temperature and light intensity line which form a slightly pointed angle. Smilax is commonly found in shady forest areas. However, certain species of Smilax are also often found on the edge areas of forest openings, namely is $S$. gigantea. An edge area is an interface between two different types of environments or ecosystems, arising between two different landscape forms or habitats (Vinter 2013). Most of the exploration and research areas are coal mining areas. Along the boundary of opening forest areas, many found Smilax gigantea. Smilax breeds with tubers, and includes the type of vines and easily spreads and grows into new individuals.

Smilax often found in areas with high humidity in range $80-85 \%$, with low lux intensity, and acid soil-pH (Table 2). Smilax species in Kalimantan forest area are commonly found in humid and shady habitats. This plant propagates and easily reproduce itself through the tubers. Ecologically, this plant functions as a ground cover. Smilax species such as $S$. leucophylla has wide leaves which is useful in absorbing the spectrum of sunlight, so that it has enough chlorophyll content (54 SPAD units) (Subro 2012).. In some places, Smilax fruit also used as sweets or consumed directly. Smilax in Kalimantan forest area is also found in acid soils, with soil-pH ranges from 3.5-5, some of them are found in a karst hill. The physical environment of the karst ecosystem is dry, especially during the dry season, and has a low fertility rate. Therefore, only certain plant and animal species are able to adapt to these environmental conditions.

\section{ACKNOWLEDGEMENTS}

We would like to thank the exploration team for the assistance in the field. This research was supported by Research Program on Plant Diversity and Habitat in coal mining exploration areas of PT. Bharinto Ekatama and PT. Indominco Mandiri, West Kutai, East Kalimantan. Both of them are PT. Indo Tambangraya Megah Tbk branch, Jakarta.

\section{REFERENCES}

Angiosperm Phylogeny Group IV. 2016. An update of the Angiosperm Phylogeny Group classification for the orders and families of flowering plants: APG IV. Bot J Linn Soc 181: 1-20.

Angiosperm Phylogeny Group III. 2009.An update of the Angiosperm Phylogeny Group classification for the orders and families of flowering plants: APG III. Bot J Linn Soc 161: 105-121.

Angiosperm Phylogeny Group II. 2003.An update of the Angiosperm Phylogeny Group classification for the orders and families of flowering plants: APG II. Bot J Linn Soc 141: 399-436.

Ashton PS. 2004. Dipterocarpaceae. In: Soepadmo E, Saw LG, Chung RCK. (eds.). Tree Flora of Sabah and Sarawak. Sabah Forestry Department, Forest Research Institute Malaysia, Sarawak Forestry Department.

Babu PV, Ashwini T, Krishna V, Raju G. 2017. Immunomodulatory and antiarthritic activities of Smilax zeylanica. Int. J Phytomedicine 8: 123-131.

Backer CA, Bakhuizenv.d. Brink RC. 1968. Flora of Java (Spermatophytes only). 3. Angiospermae, families 191-238, addenda et corrigenda, general index to volumes I-III, Volume 3. WoltersNordhoff NV, Groningen

Cameron KM, Fu C. 2006. A nuclear rDNA phylogeny of Smilax (Smilacaceae). Aliso 22 (1): 598-605.

Chen X, Koyama T. 2000. Flora of China 24: 96-115.

Cronquist A. 1981. An Integrated System of Classification of Flowering Plants. Columbia University Press, New York.

Cronquist A. 1988. The Evolution and Classification of Flowering Plants. 2nd ed. New York Botanical Garden Press, New York. 
Denk T, Velitzelos D, Güner HT, Ferrufino-Acosta L. 2015. Smilax (Smilacaceae) from the Miocene of western Eurasia with Caribbean biogeographic affinities. Am J Bot 102 (3): 423-438.

Engler A. 1964: Syllabus der Pflanzenfamilien 2. Borntraeger, Berlin.

FAO. 2006. Global forest resources assessment 2005: progress towards sustainable forest management. Forestry paper 147. FAO, Rome.

Faruque MO, Uddin SB, Barlow JW, Hu S, Dong S, Cai Q, Li X, Hu X 2018. Quantitative Ethnobotany of Medicinal Plants Used by Indigenous Communities in the Bandarban District of Bangladesh. Front Pharmacol 9: 40.

Ferrufino-Acosta L. 2010. Taxonomic revisión of the genus Smilax (Smilacaceae) in Central America and the Caribbean Islands. Willdenowia 20: 227-280.

Fu C, Kong H, Qiu Y, Cameron KM. 2005. Molecular phylogeny of the East Asian-North American disjunct Smilax sect. Nemexia (Smilacaceae). Intl J Plant Sci 166 (2): 301-309.

Djarwaningsih T, Sunarti S, Kramadibrata K. 2002. Panduan Pengolahan dan Pengelolaan Material Herbarium serta Pengendalian Hama Terpadu di Herbarium Bogoriense. Pusat Penelitian Biologi, LIPI, Bogor. [Indonesian]

Eichhorn KAO, 2006. Plant diversity after rain-forest fires in Borneo. Blumea Suppl 18: 1-140.

Gaveau DLA, Sloan S, Molidena E, Yaen H, Sheil D, Abram NK. 2014 Four Decades of Forest Persistence, Clearance and Logging on Borneo. PLoS One 9(7): e101654. DOI: 10.1371/journal.pone.0101654.

Heckroth HP, Moog J, Janka HI, Fiala B, Chung AYC, Maschwitz U. 2004. Smilax borneensis (Smilacaceae), an unspesific climbing antplant from Borneo and myrmecophytic traits in other Asiatic Smilax species. Sandakania 14: 33-50.

Hossain MA, Sanjib S, Md Asadujjaman, Shams. 2013. Analgesic, antioxidant and antibacterial activity of Smilax zeylanica Linn. (Family Smilacaceae). Pharmacol Online 1: 244-250.

Hoveizch H. 1997. Study of the vegetation cover and ecological characteristics in saline habitats of Hoor-e-Shadegan. J Res Contstr 34: 27-31.

Hutchinson J. 1973. The Families of Flowering Plants Arranged According to a New System Based on Their Probable Phylogeny. Clarendon Press, Oxford

Jena PK, Bhabani SN, Subas CD, Ellaiah P.2011. Investigation on Phytochemicals, Anthelmintic and Analgesic Activities of Smilax zeylanica Linn. Leafy Extracts. Asian J Chem 23 (10): 4307-4310.

Khan W, Khan SM, Ahmad H, Alqarawi AA, Shah GM, Hussain M, Abdallah EF. 2016. Life forms, leaf size spectra and diversity indices of plant species grown in the Thandiani forest, district Abbottabad, Khyber Pakhtunkhwa, Pakistan. Saudi J Biol Sci 25 (1): 94-100.

Langner A, Jukka M, Florian S. 2007. Land cover change 2002-2205 in Borneo and the role of the fire derived from MODIS imagery. Global Change Biol 13: 2329-2340.

Madhavan V, Hemalatha HT, Murali A, Yoganarasimhan SN. 2008. Antiepileptic activity of alcohol and aqueous extracts of roots and rhizomes of Smilax zeylanica Linn. Pharmacol Online 3: 263-272.

Martins AR, Bombo AB, Soares AN, Appezzato-da-Glória. 2013. Aerial stem and leaf morphoanatomy of some species of Smilax. Brazilian J Pharmacogn 23 (4): 576-584.

Merrill ED. 1921.A Bibliographic Enumeration of Bornean Plants. Fraser \& Neave Ltd, Singapore.

Moore BR, Narkkong NA, Moore T, Lutat P. 2008. Epicuticular leaf architecture confirms a new Smilax species (Smilacaceae) from northeast Thailand. SciAsia 34: 103-106.
Myers N, Russel AM, Cristina GM, Gustafo ABF, Jennifer K. 2000. Biodiversity hotspots for conservation priorities. Nature 403: 853-858

Qi ZC, Li P, Fu CX. 2013a. New combinations and a new name in Smilax for species of Heterosmilax in Eastern and Southeast Asian Smilacaceae (Liliales). Phytotaxa 117 (2): 58-60

Qi ZC, Li P, Du YJ, Fu CX. 2013b. Smilax jiankunii, a new synonym in Chinese Smilax (Liliales: Smilacaceae). Phytotaxa 142 (1): 58-60.

Rugayah, Retnowati A, Windadri FI, Hidayat A. 2004. Pedoman Pengumpulan Data Keanekaragaman Flora. Bogor: Pusat Penelitian Biologi-LIPI, Bogor. [Indonesian]

Rugna AZ, Gurni AA. and Wagner ML. 1999. Progress in studies on flavonols from Smilax campestris Griseb.-Smilacaceae-. Acta Hortic 501: 191-194.

Subro IL. 2012. Struktur Komunitas Tumbuhan Bawah di Kawasan Hutan Taman Nasional Gunung Halimun-Salak, Jawa Barat. Jurnal Teknik Lingkungan. Edisi Khusus "Hari Lingkungan Hidup" 57-67. [Indonesian]

Sodhi NS, Mary RCP, Tien ML, David B, Lian PK, Barry WB. 2010. The state and conservation of Southeast Asian biodiversity. Bio Conserv 19: 317-328.

Sofiah S. 2016. Struktur Floristik Marga Shorea Dan Kajian Ekologisnya Di Hutan Hujan Dataran Rendah Kawasan Bersik Bermai Kalimantan Timur. In: Biologi Perkotaan "Biologi untuk kehidupan yang harmonis alam dan manusia". Prosiding Seminar Nasional Perhimpunan Biologi Indonesia Cabang Jakarta. Universitas Nasional, Jakarta, 11 November 2015. [Indonesian]

Sofiah S, Metusala D, Trimanto, Nurfadilah S. 2018. Flora Diversity, Composition And Ecology InBesiq-Bermai Tropical Forest Of Damai District,East Kalimantan. Biotropia 25 (2): 85-94.

Sujatnika JP, Soehartono TR, Crosby MJ, Mardiastuti A. 1995. Conserving Indonesian biodiversity Bird life International and Departemen Kehutanan, Bogor.[Indonesian]

Takhtajan AL. 1987. Systema Magnoliophytorum. Nauka, Leningrad.

Takhtajan A. 1997. Diversity and Classification of Flowering Plants. Columbia University Press, New York.

Tanveer A, Tasneem M, Khaliq A, Javaid MM, Chaudhry MN. 2013. Influence of seed size and ecological factors on the germination and emergence of field bindweed (Convolvulus arvensis). Planta Daninha 31.

Tobias R. 2007. Sarsaparilla. In: Smith AF (ed.). The Oxford Companion to American Food and Drink. Oxford University Press, Oxford.

Trimanto, Sofiah S. 2018. Exploration of flora diversity and recommending species for reclamation of coal mining with biodiversity concept in Besiq-Bermai Forest, East Borneo. J Trop Life Sci 8 (2): 97-107.

Ungson LB, Sastrapradja S. 1976. Variation in Smilax species of Java. Biotrop Bull 12: 1-24.

Vinter T. 2013. Edge effects on plant species diversity in forest landscapes. Plants and Ecology. The Department of Ecology, Environment and Plant Science, Stanford University, Stanford, CA.

Van Valkenburg JLCH, Bunyaprapbatsara N. 2002. Plant Resources of South East Asia. No 12 (2). Medical and Poisonous. Prosea, Bogor, Indonesia.

Vleminckx J, Drouet T, Amani C, Lisingo J, Lejoly J, Hardy OJ. 2015. Impact of fine-scale edaphic heterogeneity on tree species assembly in a central African rainforest. J Veg Sci 26 (1): 134-44.

WCSP. 2018. World Checklist of Selected Plant Families. Facilitated by the Royal Botanic Gardens, Kew, UK.

$\mathrm{Xu} \mathrm{J}$ et al. 2005. Anti-inflammatory constituents from the roots of Smilax bockii Warb. Arch Pharm Res 28: 395-399. 